\title{
STUDENTS' PERCEPTIONS ON THE USE OF ELECTRONIC DICTIONARIES IN EFL CONTEXT: LESSON LEARNED FROM INDONESIAN VOCATIONAL HIGH SCHOOL
}

\author{
Atikah Wati \\ Universitas Wiralodra, Jln.Ir. H. Juanda Km 3, Indramayu, atikah_wati@unwir.ac.id
}

Diterima 29 Juni 2020, disetujui 25 Oktober 2020, diterbitkan 30 Oktober 2020

Pengutipan: Wati, A. (2020). Students' Perceptions On The Use Of Electronic Dictionaries In Efl Context: Lesson Learned From Indonesian Vocational High School. Gema Wiralodra, Vol 11, No 2, Hal 265-273, Oktober 2020

\begin{abstract}
ABSTRAK
Penelitian ini dilakukan dengan tujuan untuk menyelidiki persepsi siswa sekolah menengah kejuruan dalam menggunakan kamus elektronik beserta kelebihan dan kekurangannya. Studi kasus tunggal holistik digunakan sebagai metode penelitian. Kuisioner dan wawancara digunakan untuk mendapatkan data dari 19 siswa sekolah menengah kejuruan swasta di Indramayu, Jawa Barat. Temuan menunjukkan bahwa kebanyakan siswa kejuruan menggunakan Google Translate dan U-Dictionary untuk membantu mereka belajar bahasa Inggris. Sedangkan persepsi siswa tentang kamus electronic adalah 63\% siswa setuju bahwa kamus elektronik dapat membuat mereka memahami pentingnya belajar bahasa Inggris. 37\% siswa mengatakan bahwa kamus elektronik dapat meningkatkan efisiensi belajar bahasa Inggris, memotivasi dan meningkatkan bahasa Inggris mereka. 79\% siswa setuju bahwa kelebihan kamus elektronik adalah memiliki input kata yang cukup, mudah digunakan, sistem penerjemahan cepat, dan memiliki terjemahan suara, sedangkan kelemahannya hanya berkutat masalah koneksi internet dan kesalahan penerjemahan
\end{abstract}

Kata kunci: Kamus electronik, persepsi siswa, sekolah kejuruan, study kasus

\begin{abstract}
This study aimed to investigate Indonesian students' vocational high school perceptions in using electronic dictionary and its advantages and disadvantages. Holistic single case study was used as the research method. Close-ended questionnaire and interview were used to get the data from 19 students of a private vocational high school in Indramayu, West Java Indonesia. The findings indicated that most of vocational students used Google Translate and U-Dictionary to help them learning English. While in term of perception, $63 \%$ of students agree that electronic dictionary could make them understand the importance of learning English. 37\% students reported that electronic dictionary could enhance the efficiency of study English, motivate and improve their English. 79\% of students agreed that the advantages of electronic dictionaries was having sufficient words input, easy to use, fast translating system, and had voice translation, whereas the disadvantages that were reported were internet connection problem and mistranslating.
\end{abstract}

Keywords: Electronic Dictionary, Students' perception, Vocational High, School case

\section{INTRODUCTION}

Electronic dictionary is a new fastest and simple device to help students to translate English to their mother language or vice versa. As Amiran \& Heshmatifar, 2013: 36-37 cited in Nugraha, Ratnawati, \& Suratcman (2019: 38) 
contend that an "electronic dictionary aid that offers immediate access to reference information with a clear and direct return path to the target information". Yet, $\mathrm{Ng}(2016: 171)$ argues that translation provided by bilingual dictionary sometimes be misleading and so aggravate the lexical errors committed by learners.

Recent studies regarding electronic dictionaries have been done by some researchers, for instance Hamouda (2013) showed the finding that Saudi students did not take full advantages from different dictionaries available, and they are not trained on how to use dictionary maximally. The other finding showed the superiority of e-dictionary among other dictionaries. Hamdi (2015) showed his result that the ED (Electronik Dictionary) enabled students to read the text in less time than in the PD (Printed Dictionary). Despite the type of dictionary accessed did not significantly influence comprehension. With regard to vocabulary retention, The PD lookup fosters better recall of vocabulary. It was concluded that the ED more effective and motivating in aiding reading comprehension but could be detrimental to vocabulary retention. Chon (2016) indicated the findings that electronic dictionary is not an instant-problem for students' writing task due to the lack of knowledge, or when the words were known by the students but they convey it wrong in the meaning.

However, those studies focus on the use of electronic dictionary in university students and its effectiveness towards vocabulary retention and writing skill of students. Whereas, this study is restricted to investigate a private vocational high school students' perception in using electronic dictionary in their English class and this study have more focus on bilingual electronic dictionaries which provides English-Indonesia and Indonesia-English translation that is used by vocational high school students in learning activity. Therefore, this study investigated vocational high school students' perceptions in using electronic dictionaries along with its advantages and disadvantages.

\section{LITERATURE REVIEW}

\section{Definition of Perception}

James (2008: 279) contends that "perception is the consciousness of particular things presented to senses. Our senses are described as the gateways of 
knowledge or windows of the mind or soul." Perception refers to one's ultimate experience of the world and typically involves further processing of sensory input. Perception involves more process of thinking as a result of the information is received from sensory systems regards certain things or events. It is the output process where the judgement or belief were produced by an individual and it influences the way they think and feel. Perception is also a process where the one will form an impression about someone or something.

\section{Factor of Perception}

There are some factors that determine our perceptions. They are functional, structural, and attention factors (Krech \& Cruthcfield in Rakhmat, 2005: 51).

\section{Functional Factor}

Functional factor is derived from need, past experience, and other which are called personal factors. The one that determines the perception is not the kind or the form of stimuli, but characteristic of the person who bestows response to the stimuli. In addition, other personal factors that can influence someone's perception is mental readiness, emotional condition, and cultural background.

\section{Structural Factor}

Structural factor comes solely from physical stimuli and effects of nerves which it gives on an individual nerve system. Kohier in Rakhmat (2005) pinpoints that when we perceive something, we perceive it as a whole. We cannot examine separated fact but we must examine it as a whole connection. Furthermore, we need to examine the context, the environment, and the problem in understanding someone. Since there is a structure in a context, people tend to find structures in stimuli which can be categorized based on closeness and similarity.

\section{Attention Factor}

Another factor which influences perception is attention. Rahkmat (2005: 52) emphasizes it as a mental process that happens when a stimuli or series of stimuli protrude in our consciousness when the other stimuli gets weak. Stimuli are observed since it has prominent characteristics: moves, stimuli intensity, novelty, and repetition. We tend to see something that moves, colorful, new, and repeating events that something flat or not prominent. 


\section{Electronic Dictionary}

Silberztein (2016: 83-84) highlights electronic dictionary is a dictionary that can be accessed via internet and can be consulted on CD or DVD (or even can be downloaded at no cost). This dictionary can both installed in personal computer or cellphones. Silberztein (2016) also pinpoints that electronic dictionary contains larger number of obsolete, scientific, and technical terms, as well as proper names (of people, organizations and places) than the printed dictionary than contain 500.000 entries. Liu (2015: 213) argue that electronic dictionary can be called as an unimaginative use of the new powerful technologies in specialized online dictionaries.

\section{Impacts of Electronic Dictionary in Language Learning}

Digital or electronic dictionary now has grown substantially. Especially as their cost has dropped, even though to an extent they are still something of a novelty (Midlane, 2005: 29). With technology has its part on the nature of dictionary, many effects arise in its use on language learning. East (2008: 15) contends if there are no need to ask which one is better, printed or electronic. All these types of dictionary can be concluded as better tools for L2 and L1 learners based on the purpose that they address. Whereas Golonka et al (2012) highlight that they earned positive attitudes on the use of electronic dictionary when students use it and it brought more beneficial and facilitative for their learning.

\section{RESEARCH METHODOLOGY}

Grounded in holistic-single case study provides detail information about vocational high school students' perceptions in using electronic dictionaries in EFL context. Yin (2018: 88) acknowledges that holistic single-case study is the best suited for examining a global nature of an organization or a program. This study addressed 19 students (5 females and 14 males) of grade XII from TKRO (Teknik Kendaraan Ringan Otomotif), GP (Geologi dan Pertambangan), and TKJ (Teknik Komputer dan Jaringan) of a vocational high school in Indramayu.

A close-ended questionnaire modified from Boonmoh (2010) \& Dashtestani (2013) Nesi (2003), Stirling (2003), Hirata \& Hirata (2011) with 17 questions were given to the students to gather the data. And semi-structured interview with 11 questions were used to gain additional data that need more 
elaboration from the questionnaire. 5 students were chosen to follow interview section by selecting the result of questionnaire that have earned big percentage chose agree choice. The reason to pick these five students with big percentage as they might use electronic dictionary more frequently than the others, where their perception would be valid data for interview section.

\section{FINDING AND DISCUSSION}

From the questionnaire and interview, Google Translate and U-Dictionary became the most popular electronic dictionary that used by students. They indicated that electronic dictionary bestowed fast looking-up, simple to use, lightweight, and voice translation. Yet there were some problems faced by students in using electronic dictionary; Internet connection problem became the one that always faced by students. Google Translate needed internet connection to operate properly whereas U-Dictionary could be used both online and offline. Here, bad connection of internet affected Google translate which made it worked slower. Moreover, Google Translate and U-Dictionary did not always translate every English word or sentence correctly. Yet they could overcome it by asking their friend and English teacher for corrections, or they also could use printed dictionary to find the answer. Those perceptions that students showed both in functional perceptions that derived from their experiences in using electronic dictionary in English class

\section{Vocational High School Students' Perception}

The result of the first category concluded that electronic dictionaries were used by participants without any recommendation as it easy to use and fast in searching translations. This is in line with Chen (2010: 304) that argues if electronic dictionary bestows speed access for look-up than printed dictionary. Thus, participant also mentioned that electronic dictionary could motivate them in learning English and improves their English skill where it is supported by Golonka et al (2012) it could bring effectiveness and facilitative for students learning. The following table showed the students' perceptions in using electronic dictionary: 
Table 1. Students' perceptions in using electronic dictionary

\begin{tabular}{clc}
\hline No. & \multicolumn{1}{c}{ Statements } & $\begin{array}{c}\text { Percentage } \\
\text { (agree) }\end{array}$ \\
\hline 1. & $\begin{array}{l}\text { Electronic dictionaries help me to understand the } \\
\text { importance of learning English }\end{array}$ & $63 \%$ \\
2. & $\begin{array}{l}\text { Electronic dictionaries are easy to be carried } \\
\text { Electronic dictionaries were appropriate to my }\end{array}$ & $58 \%$ \\
3. $\quad \begin{array}{l}\text { English needs } \\
\text { Electronic dictionaries help me enjoy studying }\end{array}$ & $58 \%$ \\
4. $\quad \begin{array}{l}\text { English } \\
\text { Electronic dictionaries are appropriate to my }\end{array}$ & $47 \%$ \\
5. $\quad \begin{array}{l}\text { English level } \\
\text { Electronic dictionaries help me enhance the } \\
\text { efficiency of my English study }\end{array}$ & $37 \%$ \\
\hline
\end{tabular}

\section{Advatages and Disadvantages of Electronic Dictionary}

The result of category two of interview indicates that electronic dictionary had advantages such as, fast translation, easy to use, and had audio-visual features that helped students to learn new words easier. This supports the theory from Zheng \& Wang (2016) that maintain electronic dictionaries have more features that will help the learners, for instance speech-to-text ability, vocabulary journal, data transportation, internet access, and many more. Yet they also revealed diasadvantages that occured during the use of electronic dictionary. There were internet connection problem and mistranslating. The internet connection problem that conveyed by students is crossing with Casuro, Fuertes-Olivera \& Tarp (2014) cited in Liu (2015: 213) that electronic dictionary can be called as an unimaginative use of the new powerful technologies in specialized online dictionary. Internet connection problem made electronic dictionary could not work to translate and lost its power as powerful technology. Whereas mistranslating problem is in line with $\mathrm{Ng}$ (2016: 171) that bilingual dictionary sometimes be misleading and so aggravate the lexical errors. It means that bilingual electronic dictionary sometimes has mistranslating as it was one of the major problems in using electronic dictionary. The following table indicated the advatages and Disadvantages of Electronic Dictionary: 
Table 2. The advatages and Disadvantages of Electronic Dictionary

\begin{tabular}{|c|c|c|}
\hline No. & Statements & $\begin{array}{l}\text { Percentage } \\
\text { (agree) }\end{array}$ \\
\hline 1. & $\begin{array}{l}\text { Electronic dictionaries provide sufficient word } \\
\text { inputs }\end{array}$ & $79 \%$ \\
\hline 2. & $\begin{array}{l}\text { Electronic dictionaries have a simple screen and } \\
\text { layout }\end{array}$ & $74 \%$ \\
\hline 3. & $\begin{array}{l}\text { The use of electronic dictionaries enhance } \\
\text { vocabulary resources }\end{array}$ & $68 \%$ \\
\hline 4. & $\begin{array}{l}\text { Electronic dictionaries can be accessed online via } \\
\text { internet }\end{array}$ & $63 \%$ \\
\hline 5. & $\begin{array}{l}\text { Audio-visual features are used in electronic } \\
\text { dictionaries }\end{array}$ & $58 \%$ \\
\hline 6. & $\begin{array}{l}\text { Electronic dictionaries were easy to use than } \\
\text { printed dictionaries }\end{array}$ & $53 \%$ \\
\hline 7. & $\begin{array}{l}\text { Electronic dictionaries provide various word } \\
\text { examples and usage }\end{array}$ & $53 \%$ \\
\hline 8. & $\begin{array}{l}\text { Electronic dictionaries are less costly than printed } \\
\text { dictionaries }\end{array}$ & $42 \%$ \\
\hline 9. & Electronic dictionaries are easily accessible & $42 \%$ \\
\hline 10. & $\begin{array}{l}\text { Electronic dictionaries give more detailed } \\
\text { instruction about examples and usage in easy way }\end{array}$ & $37 \%$ \\
\hline 11. & $\begin{array}{l}\text { More detailed definition and meaning in electronic } \\
\text { dictionaries compared to printed dictionaries }\end{array}$ & $47 \%$ \\
\hline
\end{tabular}

Grounded from the result of questionnaire and interview, there were similiraty results between questionnaire and interview. In perceptions of students catergory showed that electronic dictionary helped students understood the importance of learning English. On other hand, electronic dictionary motivated students to love and understand English more dilligent. In addition, interview result in the same category indicated that students likely chose electronic dictionary as it could motivate and improve their English learning and it has effective and efficieny in both size of electronic dictionary that smaller than printed version but rich of information and in time where electronic dictionary could translate faster than printed dictionary.

For the advantages and dis advantages category, the result of questionnaire showed that the advantages student felt of electronic dictionary was it provided sufficient inputs of words. Which meant, electronic dictionary was built with massive words input from both Indonesia and English, allowed students to look- 
up translation without worry of insufficient words in electronic dictionary. Interview result also added that other advantages of electronic dictionary were easy to use, fast translation, and voice translation which helped students in many condition during English learning. Yet, they also informed the advantages came along, there were internet connection problem and mistranslating problem. The way they handle those issues were by asking to their classmate or English teacher and consult to printed dictionary again.

\section{CONCLUSION}

This study demostrated that positive tone of electronic dictionary which enable vocational high school students to learn English easily, especially learning and finding new words. However, students should not depend too much on electronic dictionaries whatever its types because in the end language users understand lots of various vocabularies used based on their experiences as we can say it acquisition. So practice more if you want to improve your English proficiency.

\section{REFERENCES}

Boonmoh, A. (2010). Teacher's Use and Knowledge of Electronic Dictionary. ABAC Journal, 56-74.

Chon, \& Yuah. (2016). The Electronic Dictionary for Writing: A Solution or A Problem? International Journal of Lexicography, 23-54.

East, M. (2008). Dictionary use in Foreign Language Writing Exams. Amsterdam: John Benjamins Publishing Company.

Golonka, E. M., Bowles, A. R., Richardson, D. L., \& Freynik, S. (2012). Technologies for foreign language learning: a review of technology types and their effectiveness. Computer Assisted Language Learning, DOI:10.1080/09588221.2012.700315.

Hamdi, C. (2015). The Effects of Electronic Dictionary Use on Reading Comprehension and Vocabulary Retention of EFL Students. Arab World English Journal, 180-191.

Hamouda, A. (2013). A Study of Dictionary Use by Saudi EFL Students at Qassim University. Study in English Language Teaching, 227-257. 
Liu, X. (2015). Multimodal Definition: The Multiplication of Meaning in Electronic Dictionaries. Lexicos, 210-232. doi:10.5788/25-1-1296

Midlane, \& V. (2005). Students' use of portable electronic dictionaries in the ESL/EFL classroom: A survey of teacher attitudes. Manchester, University of Manchester, UK: Unpublished Master of Education dissertation.

$\mathrm{Ng}$, C. W. (2016). Impact of the Monolingual and Bilingual Dictionaries on the Lexical Errors Commited by EFL Learners in Hong Kong: a Semantic Analysis. ASIALEX, 143-173. doi:10.1007/s40607-016-0024-0

Nugraha, G., Ratnawati, \& Surachmat, A. (2019). Exploring Low and High Students' Perception on Engaging E-Dictionary in Mastering Vocabulary: Cross-Sectional Survey. Indonesian EFL Journal, 37-44. doi:10.25134/ieflj.v5i1.1609

Rakmat, J. (2005). Psikologi Komunikasi. Bandung: PT. Remaja Karya.

Silberztein, M. (2016). Electronic Dictionaries. In Formalizing Natural Languages: The NooJ Approach (1st ed., pp. 83-109). ISTE Ltd. doi:10.1002/9781119264125.ch4

Zheng, H., \& Wang, X. (2016). The use of electronic dictionaries in EFL classroom. Studies in English Language Teaching, 144-456. 